\title{
Spatial variability in distribution and growth of juvenile and adult sea scallops Placopecten magellanicus (Gmelin) on eastern Georges Bank (Northwest Atlantic)
}

\author{
Gérard Thouzeau1 ${ }^{1}$, Ginette Robert ${ }^{1}$, Stephen J. Smith ${ }^{2}$ \\ ${ }^{1}$ Department of Fisheries and Oceans, Halifax Fisheries Research laboratory, PO Box 550, Halifax, Nova Scotia, \\ Canada B3J 2S7 \\ ${ }^{2}$ Bedford Institute of Oceanography, PO Box 1006, Dartmouth, Nova Scotia, Canada B2Y 4A2
}

\begin{abstract}
Spatial distribution of juvenile and adult sea scallops Placopecten magellanicus (Gmelin) was studied from video-monitored sled-dredge samples in commercial scallop beds of eastern Georges Bank (Northwest Atlantic). Maximum densities of 1 and 2 yr old individuals, as well as of adults, were recorded in the northern area of the study. Abundance of scallops was significantly higher on gravel than on the other sediment types. Scallops appeared to exhibit a Poisson distribution within sediment type. Distribution of juveniles only partly matched that of adults; age 1 individuals were less dispersed than 2 yr olds and adults, and were mainly located on a gravel-pebble deposit in the northern half of the Bank. It is inferred that movements associated with tidal currents occur as the individuals grow older. The relative abundances of pre-recruits and recruits emphasize the impact of fishing activity on size structure. Growth parameters of the von Bertalanffy function would indicate that Lee's phenomenon acts on the population. Age 2 juveniles showed a strong depth-related decrease in shell growth, linked to temperature and probably to food availability. The sampling technique employed has the potential for establishing pre-recruitment indices for use in management of this fishery.
\end{abstract}

\section{INTRODUCTION}

The sea scallop Placopecten magellanicus (Gmelin, 1791) supports a valuable fishery throughout its geographic range along the east coast of North America (Posgay 1957). Georges Bank, an offshore bank in the Northwest Atlantic between latitudes 41 and $42^{\circ} \mathrm{N}$, normally provides more than $50 \%$ of the landings (Serchuk et al. 1979). Commercial concentrations generally occur at depths of 40 to $100 \mathrm{~m}$ (Brown 1987). Since the early 1950's there has been continuous exploitation by both Canada and the United States, with important variations in landings (Sinclair et al. 1985). The establishment of a 200 mile $(370 \mathrm{~km})$ fishing zone by both countries (in 1977) increased competitive fishing pressure on the stocks, as respective claims overlapped on the Bank's northeastern corner. As a result of increased fishing effort, the fishery concen- trated more on incoming recruitment, and annual harvests fluctuated depending on year-class strength (Brown 1987). Despite the stock-rehabilitation strategy, fluctuations in the exploitable biomass will continue, since environmental factors may generate strong variability in year-class strength even under conditions of high adult spawning abundance (Mohn et al. 1988).

Establishment of pre-recruit (ages 1 and 2) indices would enhance predictive capacity under the enterprise allocation scheme of the Canadian fishery management strategy (Robert \& Black 1990). Stock assessment surveys give relative abundance indices only for sea scallops above 35 to $40 \mathrm{~mm}$ shell height, i.e. in their third year of life (Serchuk \& Wigley 1986). Furthermore, several aspects of the species' early life history are still poorly understood. Larval dispersion patterns have been recently studied on the Bank (Tremblay \& Sinclair 1990), but quantitative data on post-larvae and 
juveniles younger than age 3 are rare (Larsen \& Lee 1978). Settlement patterns and distribution-regulating factors on the Bank are not well understood; some postlarvae have been found byssally attached to hydrozoans, amphipod tubes and sand grains, but they accounted for a small proportion of the individuals collected (Larsen \& Lee 1978). Growth of the early benthic stages seems to be highly variable, since mean sizes at the first and second rings range from 1 to $8 \mathrm{~mm}$ and from 18 to $25 \mathrm{~mm}$, respectively (Merrill et al. 1966, Merrill \& Posgay 1967, Larsen \& Lee 1978, Posgay 1979a, Serchuk et al. 1979, Mohn et al. 1988). Decreasing shell growth with increasing depth has been reported for adults by Posgay (1979b), but neither spatial variations in juvenile growth nor growth-regulating factors have been established for Georges Bank.

This study presents the first published data on distribution, abundance and growth of juvenile sea scallops on the Canadian side of Georges Bank. The specific objectives were to locate the distribution areas of ages 1 and 2, to define growth characteristics and spatial variations within the Bank, and to examine distribution- and growth-regulating factors using published data on the Bank's environment and on behaviour patterns of post-larvae and juveniles. The study also evaluates the impact of fishing activity on the size structure and growth parameters of the population, and the potential of the sampling technique for estimating pre-recruit abundance.

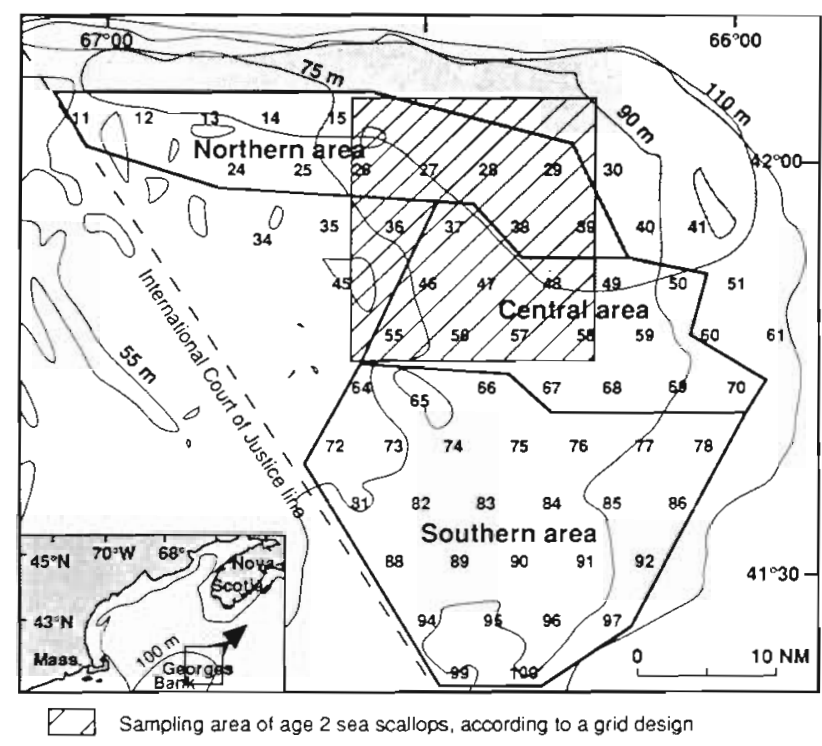

Fig. 1. Location of stations sampled with the AQUAREVE III in August 1989 on Georges Bank (Northwest Atlantic). Shaded area: pebble gravel deposit, as outlined in Lough et al. (1989). The sampling area was divided into 3 zones (northern, central and southern) to calculate mean densities of sea scallops. Age 2 scallops were also collected with a research scallop dredge to determine spatial variability in juvenile growth. NM: nautical miles

\section{MATERIALS AND METHODS}

Study sites and sampling technique. The field work was carried out on the RV 'E.E. Prince', between 23 and 29 August 1989 , from $41^{\circ} 23^{\prime} 30^{\prime \prime}$ to $42^{\circ} 03^{\prime} 30^{\prime \prime} \mathrm{N}$ and from $65^{\circ} 56^{\prime} 30^{\prime \prime}$ to $67^{\circ} 02^{\prime} 30^{\prime \prime} \mathrm{W}$ (Fig. 1). The bottom-sampling gear used was the AQUAREVE III (Application QUAntitative d'un Rabot Epibenthique avec contrôle Vidéo de l'Echantillonnage; Thouzeau \& Hily 1986), adapted from gear developed for sampling Pecten maximus (L.) juveniles (Thouzeau \& Lehay 1988. Thouzeau 1989). The AQUAREVE (Fig. 2) works like an epibenthic sleddredge, sliding on the bottom (tow speed 1 to 1.5 knots) while its knife slices the upper $5 \mathrm{~cm}$ of sediments. The working of the dredge is monitored via an underwater video camera (LVC-480 CCD B\&W Cohu camera, with $100^{\circ}$ diagonal view field) mounted on the sled and turned toward the opening of the box. While in operation, instantaneous picture transmission to the ship allows the tow to be stopped before the box overfills, and the dredging efficiency to be controlled. Two external video lights $(2 \times 250 \mathrm{~W}, 110 \mathrm{~V}$, model VLS-400) spotlight the mouth of the dredge. Distance travelled on the bottom is measured by an odometric wheel the sensor is a magnetic switch linked to an impulse counter (1-unit increase for each odometer wheel revolution) on board. In spite of a resonance artifact due to the magnet, the odometer gives a precise estimate of tow length, as the double impulses are easily detected on the counter. The opening of the dredge is $1.0 \mathrm{~m}$ wide $\times 0.4 \mathrm{~m}$ high. The collecting box is a rectangular steel box drilled with regularly spaced holes of $10 \mathrm{~mm}$ diameter; a box closing device adapted from Aldred et al. (1976) triggers when the sled leaves the bottom. The sled is towed by an electromechanical cable (steel-armoured cable, reference no. A300813, Rochester Co., Culpeper, Virginia, USA; single co-ax, 11 single conductors, belt and steel armor in a double layer with right and left helix). Electronic equipment on board includes: (1) power supplies for the camera $(12 \mathrm{~V}$ $\mathrm{DC})$, the detector $(24 \mathrm{~V} \mathrm{DC})$ and the lights $(0$ to $110 \mathrm{~V}$ $\mathrm{AC})$; (2) a 9 in. $(23 \mathrm{~cm})$ monochrome monitor (OVMYE); (3) a video cassette recorder and (4) an impulse counter.

Once on board, the samples were washed, sorted (mechanical sorting table; grid with $10 \mathrm{~mm}$ diameter holes), and preserved in $70 \%$ ethanol (juveniles) or frozen $\left(-5^{\circ} \mathrm{C}\right.$; adults $)$.

Targeted fauna and sampling design. Megabenthic animals retained by the $10 \mathrm{~mm}$ holed grid - specifically 1 yr old Placopecten magellanicus - were the targeted fauna. In August, Georges Bank age 1 scallops were expected to measure about $15 \mathrm{~mm}$ in shell height (Merrill et al. 1966, Serchuk et al. 1979, Mohn et al. 1988). Loss of some of the smallest juveniles $(<10 \mathrm{~mm})$ 

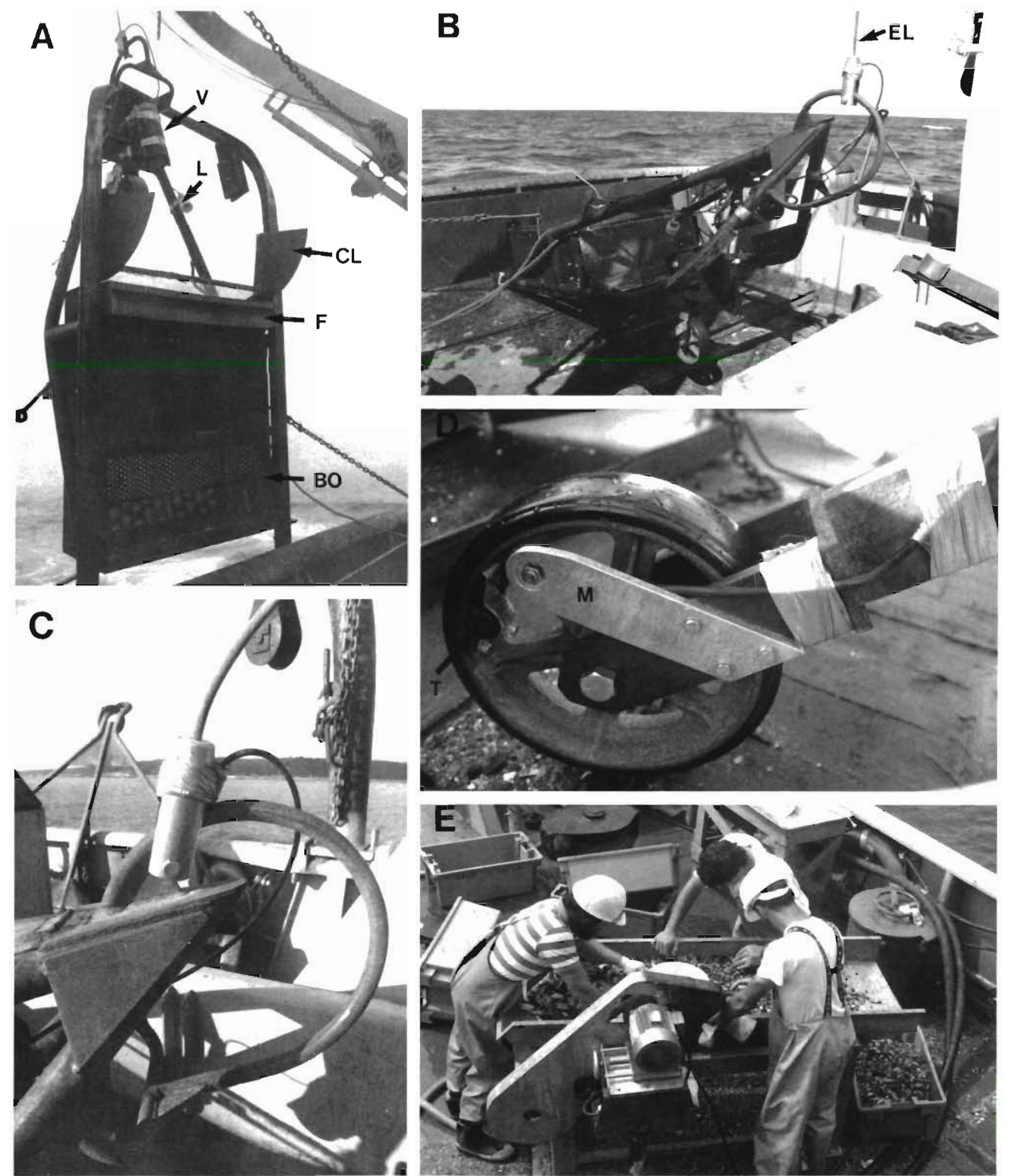

Fig. 2. AQUAREVE III sampling gear. (A \& B) Sled-dredge structure. BO: collecting box; CL: box closing device; EL: electromechanical cable; F: straight-edge knife; L: video light; V: video camera. (C) Stainless steel towing bullet with wirelock cement. (D) Odometric wheel. M: magnetic switch plate; T: trigger. (E) Sorting table 
was expected, due to dredge selectivity. Hole diameter could not be decreased, however, because of the duration of the sorting process.

A 2-dimensional systematic lattice sampling scheme (Frontier 1983) was used because little was known about the distribution and behaviour of sea scallop post-larvae and juveniles (see Larsen \& Lee 1978, Melvin et al. 1985, Caddy 1989). Furthermore, sediment types in the sampling area are not well described (Lough et al. 1989). Thirteen latitudinal transects were initially defined, spaced 4 nautical miles apart. Sampling stations were located at 4.5 nautical mile intervals along these lines. The $110 \mathrm{~m}$ isobath was defined as the outer limit of the sampling area, since Placopecten magellanicus rarely occurs in deeper waters, and usually not in commercial quantities (Posgay 1979a). The stations were positioned in alternate rows (Fig. 1) so that the distance between them was maximum; this avoids redundancy and information gaps, as may occur with a random sampling design (Frontier 1983). Of 99 potential stations within the $110 \mathrm{~m}$ isobath east of the International Court of Justice (ICJ) line, operational constraints due to bottom type, time available, and inclement weather reduced coverage to 65 stations (Fig. 1). A total area of $1776 \mathrm{~m}^{2}$ was sampled. Mean. sample size was $25.1 \mathrm{~m}^{2}$ ( $\mathrm{SD}=9.4 \mathrm{~m}^{2}$ ), with a range of 11 to $50 \mathrm{~m}^{2}$ according to sediment type.

Several samples of age 2 sea scallops were also collected during the annual stock assessment survey (17 to 22 August 1989), to determine spatial variability in juvenile growth. Use of a research scallop dredge allowed a greater sample size to be obtained, compared to the sled-dredge. Samples were collected within a grid of 64 stations (8 latitudinal transects, 8 stations per line; Fig. 1).

Data analyses. Shell height of sea scallops, i, e. the maximum distance between the dorsal (hinge) and ventral margins (Seed 1980), was recorded to the nearest $0.1 \mathrm{~mm}$ using vernier calipers. Individual ages were estimated by interpreting external growth rings on the shells, after removing epibionts (Stevenson \& Dickie 1954, Merrill et al. 1966). This technique is fairly reliable for scallops up to age 7 , although disturbance or shock marks between annual rings might lead to age overestimates (Krantz et al. 1984, Tan et al. 1988).

The effect of sediment type on spatial distribution of sea scallops was investigated using the methods discussed in McCullagh \& Nelder (1989). The number of scallops caught in each tow was expressed as number per $\mathrm{m}^{2}$. A preliminary plot of the total number of scallops per $\mathrm{m}^{2}$ indicated that the mean number for each sediment type was proportionate to the associated variance, implying that the Poisson distribution would be a reasonable model for the random effects in the data; that is, the number of scallops per $\mathrm{m}^{2}\left(y_{i j}\right)$ was assumed to exhibit a Poisson distribution within a given sediment type, so that $y_{1 j} \approx \mathrm{P}\left(\lambda_{1}\right)$, where $i$ indexes sediment type, $j$ indexes sample number and $\lambda_{j}$ is the mean for the $i$ th sediment type. If the mean numbers of scallops per $\mathrm{m}^{2}$ do differ over $i$ then the distribution of $y_{i j}$. ignoring the effect of sediment, is a mixture of Poisson distributions which is indistinguishable from a negative binomial distribution. The equality of means across sediment type was tested using an analysis of deviance (McCullagh \& Nelder 1989) and parameter estimates were obtained using GLIM (generalized linear interactive modelling) software (Payne 1985). The expected number of scallops per $\mathrm{m}^{2}$ was expressed as an exponential function of sediment type. The exponential ensures that the predicted number of scallops is $\geqslant 0$. Note that we are assuming the distributions of scallops to be Poisson at the $\mathrm{m}^{2}$ level, and therefore the total count obtained from the dredge represents a sum of Poisson random variables. Given that the distribution of the sum of Poisson random variables is also a Poisson (Johnson \& Kotz 1969), then adjusting by a constant to the $\mathrm{m}^{2}$ level should still yield a Poisson-distributed random variable.

The von Bertalanffy function was fitted to shell growth data according to the Gaschütz procedure (Gaschütz et al. 1980). This allows weighting of the data according to the number of individuals per ageclass, and estimation of the coefficient of determination. Mean shell heights for each age-class were estimated using the equation: $H_{t}=H_{x}\left[1-\mathrm{e}^{-k(t-t)}\right]$, where $H_{t}=$ shell height at time $t, H_{\infty}=$ mean asymptotic shell height, $k=$ the Brody growth coefficient and $t_{0}=$ time when shell height equals zero. Sea scallops were assigned a biological birth date of 1 st October of the year in which they were born (Posgay 1959). Thus, 12 mo old juveniles are referred to as age 1 individuals in this study. Spat were assigned a settlement date of 1 st December, to calculate average growth rates.

The depth-related size frequency distributions of age 2 juveniles were compared using a 1-way analysis of variance (unbalanced designs; SYSTAT package, Systat, Inc., Evanston, Illinois, USA).

\section{RESULTS}

\section{Spatial distribution}

The sampling area (Table 1) was divided into 3 main zones (Fig. 1), based on sediment type and location. Gravel and pebbles (particle size 2 to $15 \mathrm{~mm}$ and 15 to 64 mm respectively, similar to the scale in Buchanan \& Kain 1971) were observed in the northern area; sand mixed with gravel was observed in the central part, and sand in the southern half. Mean densities were calculated for 
Table 1. Benthic sampling stations, total numbers of scallops Placopecten magellanicus caught and mean density per station (ind. $10 \mathrm{~m}^{-2}$ ) of ages 1,2, and 3 to 7 . Samples were collected on eastern Georges Bank (Northwest Atlantic) between August 23 and 29 1989. MS: medium sand; CS: coarse sand; MiSe: mixed sediments; G: gravel; P: pebbles; R: cobbles and boulders; BB: biogenic bottom (admixture of gravel, sands and polychaete tubes); $\left({ }^{\circ}\right)$ indicates sand dunes (sand waves and megaripples). See Fig. 1 for stations

\begin{tabular}{|c|c|c|c|c|c|c|c|}
\hline Stn no. & $\begin{array}{l}\text { Depth } \\
(\mathrm{m})\end{array}$ & $\begin{array}{l}\text { Sediment } \\
\text { type }\end{array}$ & $\begin{array}{c}\text { Area sampled } \\
\left(\mathrm{m}^{2}\right)\end{array}$ & $\begin{array}{c}\text { Total scallops } \\
\text { caught }\end{array}$ & Age 1 & $\begin{array}{c}\text { Density } \\
\text { Age } 2\end{array}$ & Age $3+$ \\
\hline 11 & 57 & $\mathrm{CS}$ & 17 & 6 & & 0.6 & 3.0 \\
\hline 12 & 58 & $\mathrm{CS}$ & 11 & 2 & & & 1.9 \\
\hline 13 & 66 & MiSe & 17 & 10 & & 1.2 & 4.9 \\
\hline 14 & 66 & $P+G$ & 14 & 21 & 3.7 & 5.9 & 5.2 \\
\hline 15 & 71 & $G$ & 24 & 22 & 2.9 & 3.3 & 2.9 \\
\hline 24 & 62 & $P+G$ & 26 & 35 & 5.4 & 5.0 & 3.1 \\
\hline 25 & 66 & $G+R$ & 15 & 14 & 2.8 & 4.1 & 2.1 \\
\hline 26 & 79 & MiSe & 19 & & & & \\
\hline 27 & 77 & $\mathrm{G}$ & 14 & 35 & 6.2 & 10.3 & 7.6 \\
\hline 28 & 77 & $\mathrm{G}$ & 17 & 22 & 3.6 & 7.9 & 1.2 \\
\hline 29 & 77 & $G+P$ & 18 & 2 & & & 1.1 \\
\hline 30 & 84 & $\mathrm{BB}$ & 20 & & & & \\
\hline 34 & 66 & $\cdot \mathrm{CS}$ & 11 & 1 & 0.9 & & \\
\hline 35 & 66 & MiSe & 23 & 1 & & 0.4 & \\
\hline 36 & 73 & - MiSe & 14 & & & & \\
\hline 37 & 82 & MiSe & 17 & 3 & & 1.1 & 0.6 \\
\hline 38 & 75 & $G+P$ & 14 & 15 & 6.6 & 2.2 & 2.2 \\
\hline 39 & 77 & $G+P$ & 15 & 34 & 11.7 & 0.7 & 11.0 \\
\hline 40 & 84 & MiSe & 9 & 1 & & & 1.2 \\
\hline 41 & 91 & BB & 12 & & & & \\
\hline 45 & 68 & MiSe & 34 & & & & \\
\hline 46 & 75 & $\mathrm{CS}$ & 36 & 4 & & 0.3 & 0.8 \\
\hline 47 & 80 & $\mathrm{R}$ & 44 & 1 & & & 0.2 \\
\hline 48 & 80 & $G$ & 29 & 26 & 2.8 & 1.0 & 5.2 \\
\hline 49 & 80 & $G+R$ & 22 & 17 & 2.7 & 2.2 & 2.7 \\
\hline 50 & 90 & MiSe & 14 & 9 & & 5.0 & 1.5 \\
\hline 51 & 88 & -MiSe & 17 & & & & \\
\hline 55 & 77 & CS & 27 & 2 & & & 0.7 \\
\hline 56 & 75 & $P+R$ & 34 & 12 & 0.6 & 1.5 & 1.5 \\
\hline 57 & 77 & $G$ & 18 & 8 & 1.1 & 0.6 & 2.9 \\
\hline 58 & 80 & MiSe & 17 & 9 & 0.6 & 0.6 & 4.3 \\
\hline 59 & 82 & MiSe & 15 & 1 & & & 0.7 \\
\hline 60 & 91 & $\cdot \mathrm{MS}$ & 30 & 2 & 0.3 & & 0.3 \\
\hline 61 & 101 & $\cdot \mathrm{MS}$ & 18 & 1 & & & 0.5 \\
\hline 64 & 66 & $\cdot M S$ & 51 & & & & \\
\hline 65 & 69 & $\cdot \mathrm{MS}$ & 27 & & & & \\
\hline 66 & 75 & MS & 24 & & & & \\
\hline 67 & 80 & MS & 27 & 7 & & 1.1 & 1.5 \\
\hline 68 & 84 & $G$ & 36 & 15 & 0.6 & 1.7 & 2.0 \\
\hline 69 & 91 & MS & 20 & 4 & & 0.5 & 1.5 \\
\hline 70 & 90 & MS & 50 & 6 & & & 1.2 \\
\hline 72 & 60 & $\cdot \mathrm{MS}$ & 31 & & & & \\
\hline 73 & 68 & $\cdot \mathrm{MS}$ & 31 & & & & \\
\hline 74 & 75 & MS & 35 & & & & \\
\hline 75 & 79 & MS & 51 & 9 & & 0.4 & 1.4 \\
\hline 76 & 84 & MS & 48 & 2 & & 0.2 & 0.2 \\
\hline 77 & 91 & MS & 32 & 1 & 0.3 & & \\
\hline 78 & 88 & MS & 23 & 1 & 0.4 & & \\
\hline 81 & 77 & MS & 34 & & & & \\
\hline 82 & 79 & MS & 30 & & & & \\
\hline 83 & 82 & MS & 26 & & & & \\
\hline 84 & 82 & MS & 29 & 3 & & 0.3 & 0.7 \\
\hline 85 & 90 & MS & 34 & & & & \\
\hline 86 & 91 & MS & 23 & & & & \\
\hline 88 & 82 & MS & 29 & & & & \\
\hline 89 & 86 & MS & 55 & 1 & & & 0.2 \\
\hline
\end{tabular}


Table 1 (continued)

\begin{tabular}{|c|c|c|c|c|c|c|c|}
\hline Stn no. & $\begin{array}{l}\text { Depth } \\
\text { (m) }\end{array}$ & $\begin{array}{l}\text { Sediment } \\
\text { type }\end{array}$ & $\begin{array}{l}\text { Area sampled } \\
\qquad\left(\mathrm{m}^{2}\right)\end{array}$ & $\begin{array}{l}\text { Total scallops } \\
\text { caught }\end{array}$ & Age 1 & $\begin{array}{c}\text { Density } \\
\text { Age } 2\end{array}$ & Age $3+$ \\
\hline 90 & 88 & MS & 32 & 1 & & & 0.3 \\
\hline 91 & 86 & MiSe & 15 & 2 & & 1.3 & \\
\hline 92 & 97 & MS & 26 & 3 & & 0.8 & 0.4 \\
\hline 94 & 90 & MS & 15 & 2 & & & 1.3 \\
\hline 95 & 91 & MS & 24 & 3 & 0.8 & & 0.4 \\
\hline 96 & 88 & MS & 40 & 1 & & & 0.3 \\
\hline 97 & 104 & MS & 39 & & & & \\
\hline 99 & 88 & MS & 24 & 1 & & & 0.4 \\
\hline 100 & 90 & MS & 14 & & & & \\
\hline
\end{tabular}

Table 2. Placopecten magellanicus. Spatial variability in abundance of sea scallops on Georges Bank. Densities (per $10 \mathrm{~m}^{2}$ ) are given as mean \pm SD. The different zones are outlined in Fig. 1

\begin{tabular}{lccc|}
\hline Age-class & $\begin{array}{c}\text { Northern } \\
\text { area }\end{array}$ & $\begin{array}{c}\text { Central } \\
\text { area }\end{array}$ & $\begin{array}{c}\text { Southern } \\
\text { area }\end{array}$ \\
\hline Age 1 & $3.60 \pm 3.36$ & $0.41 \pm 0.52$ & $0.04 \pm 0.16$ \\
Age 2 & $3.43 \pm 3.18$ & $0.95 \pm 0.97$ & $0.11 \pm 0.29$ \\
Ages 3 to 7 & $3.86 \pm 2.80$ & $1.82 \pm 1.36$ & $0.21 \pm 0.37$ \\
Total & $10.9 \pm 7.10$ & $3.18 \pm 2.25$ & $0.37 \pm 0.52$ \\
\cline { 1 - 2 } & &
\end{tabular}

each zone (Table 2). The remaining stations had either sand dunes (Stns 34, 36, 51, 60,61), rocks (Stns 35, 45 , 47,56 ) with cobbles (64 to $256 \mathrm{~mm}$ particle size) and boulders (>256 mm), or biogenic bottom (Stns 30,40, 41; sediment consisted of an admixture of sands, gravel and tubes of the polychaete Filograna implexa). The distribution of Placopecten magellanicus (Fig. 3) showed maximum adult densities (age $3+$ ) in the northern area, intermediate values in the central zone within the 75 to $110 \mathrm{~m}$ depth range, and low values in the southern area (Table 2). Age 1 and 2 juveniles exhibited patterns similar to those of the adults, but were less dispersed (few individuals in the southernmost stations). Juveniles were mainly found on gravel (0.88 to 1.65 ind. $\mathrm{m}^{-2}$ ) at depths from 62 to $91 \mathrm{~m}$. Furthermore, the small-scale distribution of age 1 in the northern half of the Bank was clearly related to sediment type. In a given area, juvenile sea scallops were more abundant on gravel beds than on mixed sandy bottoms (Stns 14, $15,24,25$ vs Stns 11, 12, 13, 26, 34, 36; Stns 28, 29, 38, $39,48,49$ vs Stns 37, 50, 51, 58, 59, 60; Figs. 1 \& 3). Low densities of age 1 juveniles were found at rocky stations $(35,47,56)$, but not on biogenic bottom.

Results of the analysis of deviance to evaluate the statistical significance of sediment type are given in Table 3 . The theory of generalized linear models is

Fig. 3. Placopecten magellanicus. Distribution of sea scallops (ages 1, 2, and 3 to 7) on eastern Georges Bank. Samples were collected with the AQUAREVE III in August 1989, and catches were standardized to numbers of individuals per $10 \mathrm{~m}^{2}$ (upper and lower limits shown for each symbol size)

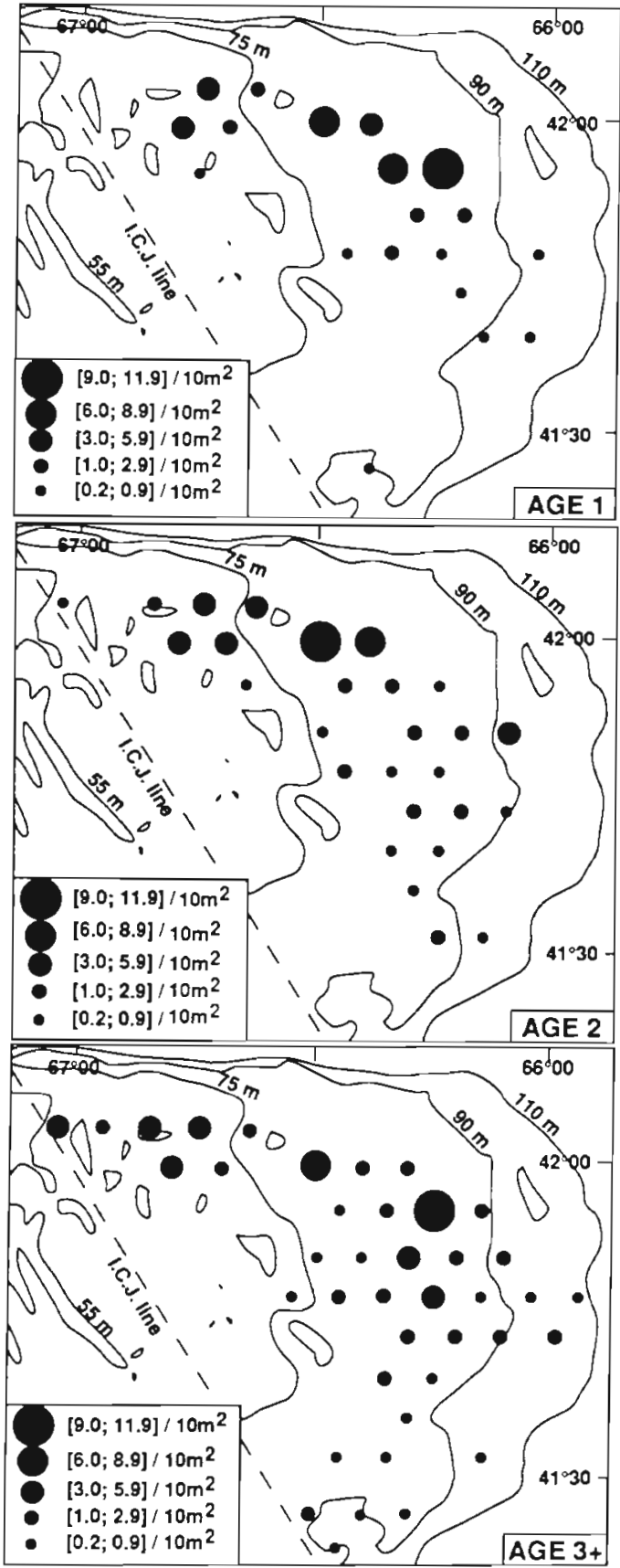


based on the measure of the discrepancy between observations and the fitted values from a model, calculated from the logarithm of the ratio of the respective likelihoods as deviance (McCullagh \& Nelder 1989). The significance of the amount of deviance explained by sediment type was assessed by a $\chi^{2}$ test; sediment type did explain a significant portion of the deviance (Table 3a). The parameter estimates (Table 3b) indicate

Table 3. Results of fitting a Poisson model to the frequency distribution of the total number of sea scallops Placopecten magellanicus caught in each tow of the sled-dredge AQUAREVE III. Variables as follows: Mean $=$ Grand mean; Sediment $=$ bottom sediment type; the p-level refers to a $\chi^{2}$ statistic; Mixed $=$ mixed sediments; Coarse $=$ coarse-grain sand ; Gravel = gravel-pebble deposit ; Cobbles $=$ cobbles and boulders plus biogenic bottoms; Medium = medium-grain sand

\begin{tabular}{|lcccc}
\hline \multicolumn{5}{|c}{ (a) Analysis of deviance for Poisson error with log link: } \\
$\begin{array}{l}\text { Model } \\
\text { First difference } \\
\text { in deviance }\end{array}$ & df & p-level & Scale \\
\hline $\begin{array}{l}\text { Mean } \\
+ \text { Sediment }\end{array}$ & 28.32 & 4 & $<0.0001$ & 0.2084 \\
\hline
\end{tabular}

(b) Parameter estimates for final model: Mean + Sediment: Parameter Estimate Standard error

\begin{tabular}{lrr}
\hline Mean & -1.819 & 0.507 \\
Mixed-Coarse & 0.163 & 0.589 \\
Gravel-Coarse & 1.926 & 0.521 \\
Cobbles-Coarse & -0.546 & 0.900 \\
Medium-Coarse & -1.152 & 0.621 \\
\hline
\end{tabular}

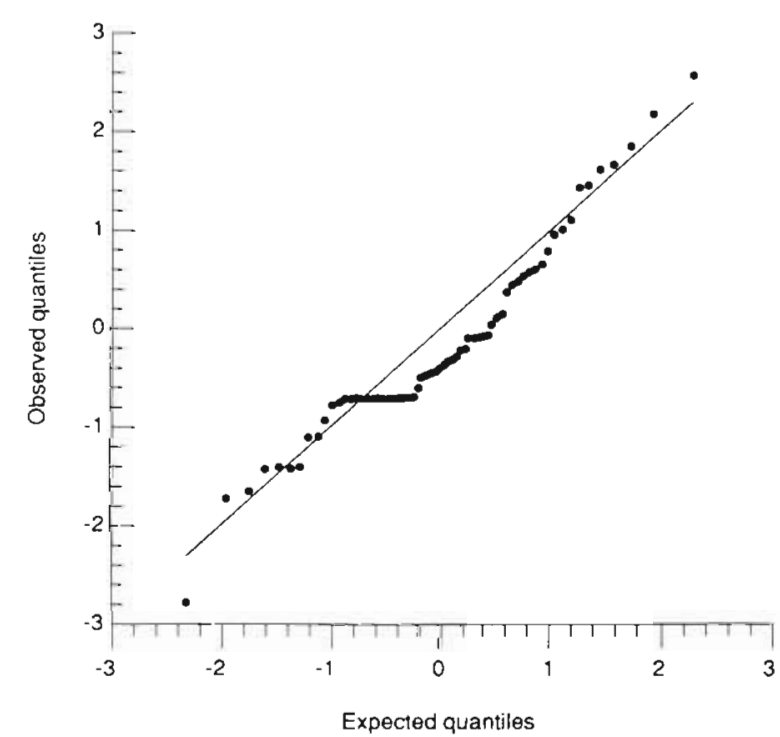

Fig. 4. Placopecten magellanicus. Quantile-quantile plot of scaled deviance residuals from the Poisson model for sea scallops (ages 1 to 7) caught with the AQUAREVE III in August 1989. Catches were standardized to numbers of individuals per $\mathrm{m}^{2}$ that the sediment effect was mainly due to more scallops being found on gravel than on coarse-grain sand. Differences between the other sediment types and coarse sand were much smaller. All the differences are expressed on a logarithmic scale.

The distribution of deviance residuals should be approximately normal if the random component of the model is reasonably similar to patterns in the data (Pierce \& Schafer 1986). The quantiles of the scaled deviance residuals (McCullagh \& Nelder 1989) from
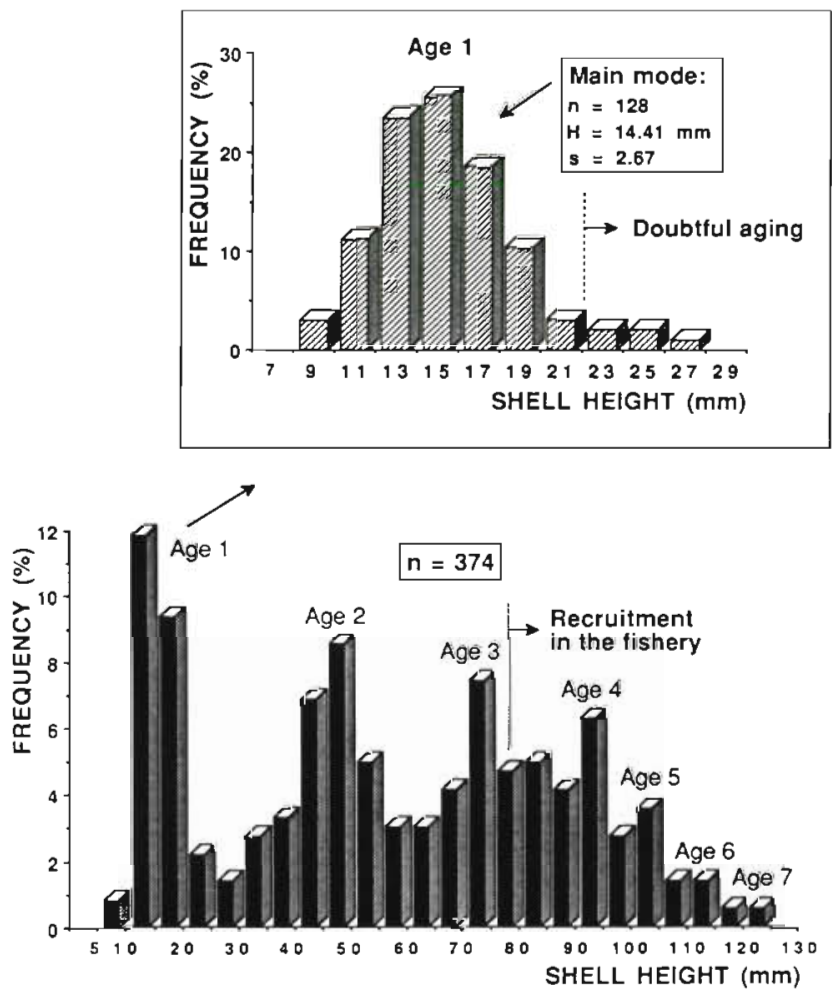

Fig. 5. Placopecten magellanicus. Size-frequency distribution of sea scallops sampled with the AQUAREVE III on Georges Bank (23 to 29 August 1989). Size distributions are shown for all year-classes sampled and age 1 individuals (detailed). Age at recruitment also indicated. $n$ : number of scallops; $H$ : mean shell height; s: standard deviation

Table 4. Placopecten magellanicus. Mean shell height per age-class (plus $95 \%$ confidence intervals, $\mathrm{Cl}$ ) of sea scallops collected with the AQUAREVE III on Georges Bank (August 23 to 291989 )

\begin{tabular}{|ccccc|}
\hline $\begin{array}{c}\text { Age- } \\
\text { class }\end{array}$ & $\begin{array}{c}\text { No. of } \\
\text { indivi- } \\
\text { duals }\end{array}$ & $\begin{array}{c}\text { Mean shell } \\
\text { height } \\
(\mathrm{mm})\end{array}$ & $\mathrm{SD}$ & $95 \% \mathrm{CI}$ \\
\hline 1 & 98 & 14.39 & 2.71 & $13.94-14.88$ \\
2 & 112 & 44.52 & 7.82 & $43.05-45.99$ \\
3 & 81 & 72.00 & 6.06 & $70.66-73.34$ \\
4 & 50 & 89.52 & 3.85 & $88.43-90.61$ \\
5 & 21 & 101.71 & 2.53 & $100.56-102.86$ \\
6 & 9 & 112.00 & 2.74 & $109.89-114.11$ \\
7 & 3 & 121.00 & 1.41 & $116.71-125.29$ \\
\hline & & & & \\
\hline
\end{tabular}




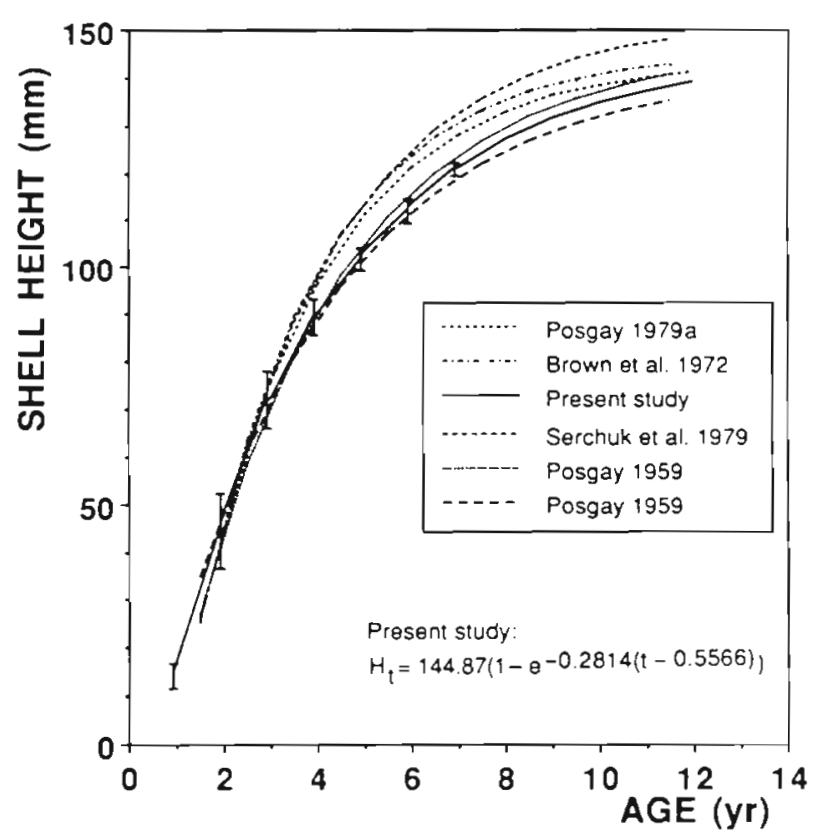

Fig. 6. Placopecten magellanicus. Age-specific shell heights fitted to von Bertalanffy equations for sea scallop populations from Georges Bank, according to different studies. Mean height and $95 \%$ confidence intervals are added to the growth curve from the present study

Table 5. Placopecten magellanicus. Parameters of the von Bertalanffy equations describing shell height $(H, \mathrm{~mm})$ as a function of age $(\mathrm{yr})$ in sea scallops from Georges Bank. Data fitted to the equation $H_{t}=H_{x}\left[1-e^{-k\left(t-t_{0}\right)}\right]$, where $H_{t}=$ height at age $t_{i} H_{x}=$ mean asymptotic height; $k=$ Brody growth coefficient; $t_{0}=$ a parameter representing time when $H_{t}=0$. n: no. of observations

\begin{tabular}{|c|c|c|c|c|}
\hline Source & $H_{\infty}$ & $k$ & $t_{0}$ & $n$ \\
\hline Posgay (1959) & 146.5 & 0.30 & 1.32 & 426 \\
\hline Posgay (1959) & 141.8 & 0.28 & 1.00 & 254 \\
\hline Posgay (1962) & 148.9 & 0.26 & 1.0 & NK \\
\hline Brown et al. (1972) & 145.5 & 0.38 & 1.50 & NK \\
\hline Posgay (1979a) & 143.6 & 0.37 & 1.00 & 7000 \\
\hline Serchuk et al. (1979) & 152.46 & 0.3374 & 1.4544 & NK \\
\hline Present study & 144.87 & 0.2814 & 0.5566 & 374 \\
\hline
\end{tabular}

the model were compared with expected quantiles from a normal distribution (Fig. 4). Deviations from the normal appear to be slight, and therefore we can assume that the Poisson distribution is a reasonable model for the random component.

Size-frequency distribution and shell growth rate. Size of sea scallops collected with the sled-dredge ranged from 9 to $122 \mathrm{~mm}$ in shell height (Fig. 5). This corresponded to 7 age-classes (Table 4 ), of which age 1 $(26.2 \%)$ and age $2(29.9 \%)$ made up $56 \%$ of the total. Mean shell height of $1 \mathrm{yr}$ olds in August was $14.4 \pm 2.67 \mathrm{~mm}$. The height ranged from 8 to $22 \mathrm{~mm}$ for the main mode, with few larger individuals (5.1\%).
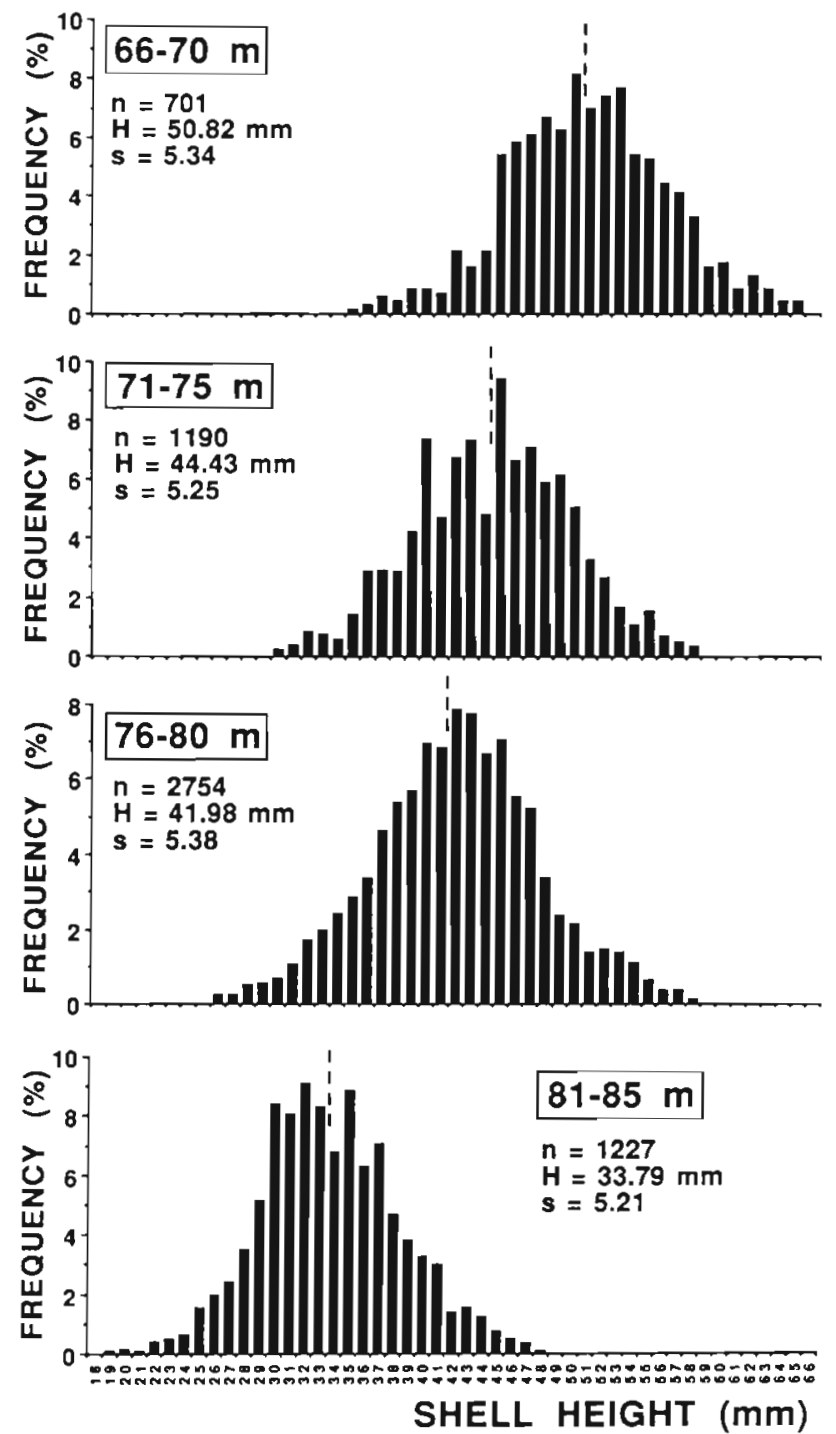

Fig. 7. Placopecten magellanicus. Size-frequency distribution of 2 yr old sea scallops with respect to depth, on Georges Bank. Samples were collected during the stock assessment survey (17 to 22 August 1989). n: number of scallops; H: mean shell height; s: standard deviation

Growth parameters of the von Bertalanffy function (Fig. 6) are $H_{x}=144.87 \mathrm{~mm}, k=0.2814$ and $t_{0}=$ 0.5566 . The von Bertalanffy model provides a good fit to the shell data $\left(r^{2}=0.998\right)$. The present growth curve is the only one from Georges Bank (results from previous studies shown in Table 5 and Fig. 6) using data for age 1 scallops.

Spatial growth variations. Up to $58722 \mathrm{yr}$ old sea scallops collected during the stock assessment survey were measured to determine spatial variability in juvenile growth. Shell height histograms plotted against 4 depth ranges (Fig. 7) show that mean shell height varied with depth. A mean size reduction of $33.3 \%$ was observed between the shallowest (65 to 69 $\mathrm{m})$ and the deepest ( 81 to $85 \mathrm{~m}$ ) waters. The 4 depth- 
Table 6. Placopecten magellanicus. Comparison of size-frequency distributions of 2 yr old sea scallops according to depth. Distributions were fitted by pairs and tested with Pearson and likelihood-ratio chi-square statistics (99\% probability level)

\begin{tabular}{|cccccc|}
\hline $\begin{array}{c}\text { Depths fitted } \\
(\mathrm{m})\end{array}$ & $\begin{array}{c}\text { Pearson's } \\
\text { chi-square }\end{array}$ & $\begin{array}{c}\text { Likelihood-ratio } \\
\text { chi-square }\end{array}$ & df & $\begin{array}{c}\text { Tabulated chi-square } \\
\text { (99\% p.l.) }\end{array}$ & Probability \\
\hline $65-70 / 71-75$ & 471.37 & 508.99 & 26 & 45.64 & 0.000 \\
$71-75 / 76-80$ & 231.16 & 229.62 & 30 & 50.89 & 0.000 \\
$76-80 / 81-84$ & 1485.31 & 1616.47 & 22 & 40.29 & 0.000 \\
\hline
\end{tabular}

related distributions were compared with a 1-way analysis of variance (test of differences in the mean height at each depth), after the homogeneity of variances was tested (Cochran test in Winer 1971). According to Winer (1971) and Underwood (1981), a small departure from homogeneity of variances (calculated value of $\mathrm{C}=0.257$; critical value $=0.250$, for $k=4$ and $\mathrm{df}=\infty$ ) does not seriously affect the sampling distribution of the $F$ statistic. Variations in shell height were significant ( $99 \%$ probability level), with respect to depth ( $F$ ratio $=1541.71>3.78$ for $\mathrm{df} 1=3$, df $2=5867)$. As the second ( 70 to $75 \mathrm{~m}$ ) and third $(75$ to $80 \mathrm{~m}$ ) depth ranges showed smaller differences for mean shell height and variance, the height distributions were compared by pairs (test of differences in the distribution of height). Fitted distributions were tested with both Pearson and likelihood-ratio chi-square statistics (frequencies $<5$ combined). Calculated values of chi-square (Table 6) indicate that all the differences in size-frequency distribution were significant (99\% probability level).

\section{DISCUSSION}

\section{Sampling efficiency}

The rate at which Pecten maximus juveniles were caught with the AQUAREVE technique was evaluated using SCUBA (Thouzeau \& Lehay 1988). The device was more than $80 \%$ efficient under good weather conditions. Depths on Georges Bank did not allow such a controlled experiment for Placopecten magellanicus. Fishing dredges trigger an avoidance response when disturbing a scallop bed (Caddy 1968, Thomas \& Gruffydd 1971, Stephens \& Boyle 1978). Compared to Pecten maximus, Placopecten magellanicus may tend to avoid the sled-dredge more, since it usually does not live recessed in the sediment and is a better swimmer. Sea scallops approach optimum hydrofoil shape for lowaspect body ratio (Hoerner 1975, Dadswell \& Weihs 1990); an average swimming speed of $0.48 \mathrm{~m} \mathrm{~s}^{-1}$ (up to $0.80 \mathrm{~m} \mathrm{~s}^{-1}$ ) has been reported (Caddy 1968, Dadswell \& Weihs 1990). Thornbun \& Gruffydd (1979) established that, of 4 scallop species tested, P. magellanicus was the most hydrodynamically suited for swimming.
The efficiency of the sled-dredge might vary depending on individual sizes, since medium-sized Placopecten magellanicus ( 40 to $80 \mathrm{~mm}$ shell height) are the best swimmers (optimal hydrodynamic characteristics; Dadswell \& Weihs 1990). Larger and smaller sea scallops swim not only at lower velocities but also at lower relative velocities (no. of body lengths $\mathrm{s}^{-1}$ ). During the tows, several individuals were observed (on the video) swimming away from the dredge and at times escaping the sampling box. Scallops moving out of the path of the dredge could not be seen, because of the camera's orientation. However, any escape from the collecting box during hauling to the surface was prevented by the box closing device.

\section{Distribution patterns}

The main features of scallop distribution in this study were the concentration of sea scallops in the northern half of the Bank and the dispersion of individuals as they grow older (Fig. 3). Physical aggregation at the larval stage, substrate selection at settlement, postlarval differential mortality, or juvenile movement (broader initial distribution and migration to the most suitable areas for survival and growth) may explain these patterns. Settlement is assumed to occur by midDecember on Georges Bank (Merrill \& Edwards 1976 , Larsen \& Lee 1978, Tremblay \& Sinclair 1990). In contrast to other pectinid post-larvae (Brand et al. 1980, Orensanz 1986), it seems unlikely that Placopecten magellanicus has an obligatory settlement substrate or an obvious preference (Caddy 1973, Naidu \& Scaplen 1976. Caddy \& Carter 1984). However, sea scallops occur at lower densities on mud than on sand (Caddy 1970, 1989, Langton \& Robinson 1990). Experiments on settlement behaviour suggest a general thigmotactic response in pediveligers (Baird 1953, Caddy 1972, Culliney 1974). The attachment of post-larvae to various substrates in nature supports this view; sea scallop spat have been found attached to shells of live Placopecten magellanicus (Naidu 1970), shell fragments (Caddy 1968), bryozoans (Baird 1953, Caddy 1972), hydrozoans, amphipod tubes, and sand grains (Larsen \& Lee 1978), red algae (Naidu 1970), and metal 
and wooden navigation buoys (Merrill \& Posgay 1967, Naidu 1970, Merrill \& Edwards 1976). The present study only partially supports this generalization, since $76.5 \%$ of the 1 yr olds were located on gravel and pebbles and the remainder on sandy bottoms with shell debris. Furthermore, the small-scale distribution of age 1 in the northern half of the Bank was clearly related to sediment type (juveniles more abundant on gravel beds than on mixed sand-gravel bottoms). Ongoing studies confirm this result, since more than $50 \%$ of 19 mo old individuals were found attached to gravel and pebbles in late April 1990 (shell height ranging from 13 to $27 \mathrm{~mm}$ ).

The fact that juvenile abundance was greatest on gravel might reflect enhanced survival on this bottom type, as suggested by Larsen \& Lee (1978) and Castagna \& Kraeuter (1977) for Mercenaria mercenaria. Gravel might enhance juvenile protection from predation (spat settle predominantly on the underside of gravels or shell fragments; Culliney 1974), allowing sufficient water to surround the individuals while acting as a barrier to epibenthic predators. Pebbles and gravel may also offer a more stable substratum for settlement than does shell debris, in areas where strong tidal currents occur. Since pediveliger larvae are capable of delaying metamorphosis for at least 1 mo and retain their swimming ability (Culliney 1974), they might be able to choose the appropriate substratum for settlement.

Larval drift is a function of the depth-averaged residual current (mixed areas) or of the current above or within the pycnocline (stratified waters) on the Bank (Tremblay \& Sinclair 1990). Sea scallop larvae do circulate in the direction of the residual currents but are not spread over the entire Bank (J. Tremblay, Dept of Fisheries \& Oceans, pers. comm.). Larval abundance appears to be reduced in the well-mixed area $(<60 \mathrm{~m})$, while late-stage larvae are frequently abundant on the Northern Flank. A clockwise circulation occurs around Georges Bank, which requires 33 to $60 \mathrm{~d}$ for completion, depending on depth and season (Butman et al. 1982, 1987, Lough \& Trites 1989). Given the duration of the larval stage on the Bank (40 to $60 \mathrm{~d}$; J. Tremblay pers. comm.) and regardless of diffusion process, some scallop larvae could be returned to the vicinity of the parental beds at metamorphosis. Other larvae may remain on the shallower part of the Northeast Peak because of lower residual currents (Lough \& Trites 1989).

Several studies, mainly performed in inshore areas, indicated an absence of directed population movements or seasonal migrations in adult Placopecten magellanicus (Dickie 1955, Posgay 1963, Krantz et al. 1984). However, localized movements were recorded on Georges Bank ( 8 to $10 \mathrm{~km} \mathrm{yr}^{-1}$ on average), their direction corresponding with bottom-water residual currents (Posgay 1982, Melvin et al. 1985). In this study, age-classes show different distribution patterns, with a clear drift to the south (age 2) and southwest (age 3+) as the individuals grow older (Fig. 3). The dispersion with age (in an arc, oriented northwest-southeast) supports the hypothesis of current-related dispersion (on a small scale) during the benthic phase. These results agree with previous studies on adult distribution on Georges Bank (Robert et al. 1982, Robert \& Black 1990) and in the Gulf of Maine (Serchuk \& Wigley 1984). The more localized distribution of age 1 juveniles may be partly explained by their sedentary behaviour (byssal attachment), while the spread of older individuals corresponds to the motile phase $(30$ to $100 \mathrm{~mm}$ shell height; Caddy 1968) with optimal hydrodynamic characteristics (Dadswell \& Weihs 1990). The impact of fishing activity on sea scallop dispersion through the capture and release of pre-recruits cannot be assessed here.

Based on the foregoing observations, we suggest that the distribution of juvenile sea scallops is mainly determined by physical processes (advection) during the larval stage and by differential post-larval mortality (according to sediment type) at settlement. Tides and storm events on Georges Bank may give a strong element of temporal variability to the direction and speed of residual currents (Butman et al. 1982). Hence, larval dispersal and settlement areas are likely to vary among years,

On Georges Bank, the higher abundance of sea scallops (especially 1 yr olds) on gravel than on the other sediment types agrees with the spatial distribution of Placopecten magellanicus adults in the Gulf of St. Lawrence and Gulf of Maine (Caddy 1970, Langton \& Robinson 1990). Scallops appeared to exhibit a Poisson distribution within sediment type in the present study, in contrast to the findings of Langton \& Robinson (1990). Age 1 Pecten maximus in the Bay of SaintBrieuc also displayed aggregated distribution at the bay scale, and random distribution within patches (Thouzeau \& Lehay 1988, Thouzeau 1989). Differences may be due to the greater size of the sampling units in the present study ( $\geq 11 \mathrm{~m}^{2}, 25.1 \mathrm{~m}^{2}$ on average) compared to that of Langton \& Robinson (1990) $\left(1.24 \mathrm{~m}^{2}\right.$ quadrats). If the size of sampling units is much larger than the average size of clumps of individuals, and these clumps are regularly or randomly distributed, then the dispersion of the population is apparently random and the non-randomness is not detected (Elliott 1977). Langton \& Robinson (1987) established that adult sea scallops in the Gulf of Maine $(60$ to $88 \mathrm{~m}$ depth range) were generally separated by a distance of at least 25 to $60 \mathrm{~cm}$. This cannot be determined for the present study. 


\section{Size structure and growth parameters}

Seven age-classes ( 1 to 7 ) were sampled in this study, though scallops up to age 12 are caught on Georges Bank (Brown 1987). However, few specimens $(1.9 \%$ in 1989) over age 7 are caught in commercial scallop dredges (Robert \& Black 1990), as for other heavily exploited scallop beds (Langton et al. 1987). Compared to that of recruits (Fig. 5), pre-recruit abundance (ages 1 to $3=78 \%$ of total numbers) emphasizes the impact of fishing activity on the size or age structure, even if older individuals might have been underestimated because of their wider dispersion.

Several studies fitting shell growth data to the von Bertalanffy model are available for the Georges Bank area (Posgay 1959, 1962, 1979a, Brown et al. 1972, Serchuk et al. 1979). Asymptotic heights, $H_{\infty}$, range from 141.8 to $152.46 \mathrm{~mm}$, while $k$ varies from 0.26 to 0.38 . Through its geographic range, greater variations are observed for $H_{\infty}$, from $108.83 \mathrm{~mm}$ in the southwestern Gulf of St. Lawrence (Chouinard 1984) to $207 \mathrm{~mm}$ on the northeastern coast of Maine (Langton et al. 1987). As pointed out by MacDonald \& Thompson (1988), care must be taken when comparing von Bertalanffy derived growth rates from different populations or samples. Comparisons based on the Brody coefficient $k$ are inappropriate when the asymptotic heights or lengths are very different, because $k$ is inversely related to $H_{\infty}$. Furthermore, $k$ is a growth coefficient and should not be regarded as growth rate per se (Ricker 1975). Asymptotic height in the present study $(144.87 \mathrm{~mm})$ is similar to the value of $145.5 \mathrm{~mm}$ given by Brown et al. (1972) for Georges Bank. However, $k$-which determines the steepness of the curve is much lower in our study (0.2814) than in Brown et al. (0.38). Differences may result from the inclusion of data for ages 1 and 2 in our study (56\% of scallop numbers, versus $0 \%$ in Brown et al.) and from sampling locations in the 2 studies [South Channel and southeastern part of the Bank in Brown et al. (1972); Northeast Peak in the present study]. There may also be some form of 'Rosa Lee's phenomenon' (Ricker 1975) acting on the exploited population, as shown by Chouinard (1984). Heavy fishing would lead the stocks to be mainly composed of slower-growing individuals. These would become available to the fishery at an older age due to size-selectivity of the gear. Further investigations (greater sample size) are needed to validate this hypothesis for the Georges Bank scallop population.

\section{Early growth of sea scallops}

The first shell ring of scallops on Georges Bank is formed in March-April (Merrill et al. 1966, Posgay 1979a), at about 6 to $8 \mathrm{~mm}$, although Larsen \& Lee (1978) have shown that it may form at a smaller size (0.2 to 2.8 $\mathrm{mm}$ ). Mean sizes at the second and third rings range from 18 to $25 \mathrm{~mm}$ and from 48 to $63 \mathrm{~mm}$, respectively (Merrill \& Posgay 1967, Posgay 1979a, Serchuk et al. 1979, Mohn et al. 1988, Caddy 1989). The mean shell height of 1 yr olds in the present study is similar to that reported on the Northern Edge and Peak region of the Bank (Serchuk \& Wigley 1984), but lower than that recorded in the shallower waters $(23 \mathrm{~m}$ ) of Cape Cod Bay, Massachusetts (mean height 17 to $18 \mathrm{~mm}$ ). Faster growth rates are usually recorded for spat held in suspended culture (MacDonald 1986, Dadswell 1989). A mean shell height of ca $22 \mathrm{~mm}$ by late August was regularly obtained in Passamaquoddy Bay (southwestern New Brunswick), following fall settlements (Dadswell 1989). An average growth rate of $51.5 \mu \mathrm{m} \mathrm{d}^{-1}$ during the first year of life was found in the present study, compared to 60 to $65 \mu \mathrm{m}$ $\mathrm{d}^{-1}$ in Passamaquoddy Bay (Dadswell 1989).

Scallops 2 yr old exhibited significant variations in shell growth (Fig. 7) over a small depth range (65 to 84 $\mathrm{m})$ in this study. Decreasing shell growth with increasing water depth has been reported in a number of studies from the Bank (Posgay 1979b) and elsewhere (Caddy 1970, MacDonald \& Thompson 1985, 1988). The latter showed that growth variations along a depth gradient on a micro-geographical scale were equal to or greater than variations on a latitudinal scale. Growth differences were ascribed to food and temperature conditions, although several studies did not provide quantitative evidence of lower food availability in deeper water. Spatial variations in bottom-water temperature of about $2^{\circ} \mathrm{C}$ (60 to $100 \mathrm{~m}$ depth range) in summer occur on Georges Bank within the sampling area for juveniles (Dickinson \& Wigley 1981, Flagg 1987). Summer temperatures usually decrease from $12^{\circ} \mathrm{C}$ at $60 \mathrm{~m}$ to $10^{\circ} \mathrm{C}$ at $100 \mathrm{~m}$ (Flagg 1987 ), although lower values have been recorded (from 9 to $7^{\circ} \mathrm{C}$; Butman \& Beardsley 1987). Depending on the year, the thermocline may persist in fall (up to $6^{\circ} \mathrm{C}$ temperature difference) or disappear (Loder et al. 1982, Flagg 1987, Tremblay \& Sinclair 1990). According to Posgay (1953), sea scallops grow faster at $10^{\circ} \mathrm{C}$ (max. growth rate) than at $12{ }^{\circ} \mathrm{C}(80$ $\%$ of max. growth rate) or $8{ }^{\circ} \mathrm{C}(95 \%$ of max. growth rate). However, larvae are successfully reared in hatcheries at temperatures of 12 to $15^{\circ} \mathrm{C}$ (Culliney 1974, Hurley et al. 1987), the upper thermal tolerance limit being about $19^{\circ} \mathrm{C}$ (Culliney 1974). Temperatures higher than 15 to $16^{\circ} \mathrm{C}$ would be above the optimum for adults in Newfoundland waters (MacDonald \& Thompson 1985). Given that bottom-water temperatures and juvenile growth rates are higher at 65 to $70 \mathrm{~m}$ than at 80 to $85 \mathrm{~m}$ on Georges Bank, high summer temperatures are unlikely to have a detrimental effect on growth within the 65 to $85 \mathrm{~m}$ depth range. 
Food availability also presents depth-related variations on Georges Bank. A chlorophyll a concentration (phytoplankton biomass) of about $8 \mathrm{mg} \mathrm{m}^{-3}$ has been recorded close to the bottom at $50 \mathrm{~m}$, versus $<4 \mathrm{mg} \mathrm{m}^{-3}$ at $80 \mathrm{~m}$ and $<1 \mathrm{mg} \mathrm{m}^{-3}$ at $110 \mathrm{~m}$ (Cohen \& Wright 1978). Furthermore, a comparable cross-bank gradient from shallow to deep water was found in the sizefrequency and species composition of the phytoplankton (O'Reilly et al. 1987). In Gulf of Maine scallop populations, Shumway et al. (1987) showed that gut contents generally reflected food organisms available in surrounding waters (algae 10 to $350 \mu \mathrm{m}$ in size, pollen grains, ciliates, detritus, bacteria). They concluded that Placopecten magellanicus is an opportunistic feeder taking advantage of any food available. On the Bank, one cannot discount the possible importance of particulate organic matter in the benthic boundary layer as scallop food. It cannot be concluded from the present study whether temperature or food availability is the main cause of decreased growth with depth.

This study documents the distribution patterns of sea scallops on Georges Bank and suggests the importance of sediment type for the survival of newly settled postlarvae. These results provide a basis for further investigation into the roles of habitat type, dispersion patterns and food availability in relation to successful recruitment of sea scallops. The study also points out the effect of heavy fishing on size structure, and its likely effect on growth. The strong depth-related decrease in shell growth emphasizes the inadequacy of using only 1 averaged growth curve for the entire Bank. The northern half of Canadian Georges Bank, especially the main pebble-gravel deposit, provides the most appropriate substrata for post-larval settlement and exhibits the highest densities of juveniles. The establishment of pre-recruit indices for incoming yearclasses prior to age 3 would require that this area be targeted to collect more individuals

Acknowledgements. We thank Captain P. Antle and the crew of the RV 'E.E. Prince', and C. Dibacco, A. Hennigar, and M. Lundy, for valuable assistance during the cruise. R. Vine and the welders from the Bedford Institute of Oceanography built the sled. R. Duggan, I Foulkes, D. Stewart and P. Vass advised on electromechanical cable. Goodspeeds Ltd (Halifax) built the termination on the cable, supplied the video equipment, and maintained gear Jourdan S.A. (France) built the sorting table. The manuscript benefited from comments by M. Sinclair, M. J. Tremblay and J. D. Pringle.

\section{LITERATURE CITED}

Aldred, R. G., Thurston, M. H., Rick, A. L., Morley, D. R (1976). An acoustically monitored opening and closing epibenthic sledge. Deep Sea Res. 23: 167-174

Baird, F. T Jr (1953). Observations on the early life history of the giant scallop (Pecten magellanicus). Maine Dept. Sea Shore Fish. Res. Bull. 14: 1-7 (mimeo)

Brand, A. R., Paul, J. D., Hoogesteger, J. N. (1980). Spat settlement of the scallops Chlamys opercularis (L.) and Pecten maximus ( $\mathrm{L}$.) on artificiai collectors. J. mar biol. Ass. U.K. 60: $379-390$

Brown, B. E. (1987). The fisheries resources. In: Backus, R. H., Bourne, D. W. (eds.) Georges Bank. MIT Press, Cambridge, Massachusetts, p. 480-493

Brown, B. E., Parrack, M., Flescher, D. D. (1972). Review of the current status of the scallop fishery in ICNAF division $5 Z$. Int. Comm. Northw. Atl. Fish. (ICNAF) Res. Doc. 72/113: $1-13$

Buchanan, J. B., Kain, J. M. (1971). Measurement of the physical and chemical environment. In: Holme, N. A., McIntyre, A. D. (eds.) Methods for the study of marine benthos. IBP Handbook 16. Blackwell Scientific Publications, Oxford \& Edinburgh, p. 30-58

Butman, B., Beardsley, R. C. (1987). Physical oceanography. In: Backus, R. H., Boume, D. W. (eds.) Georges Bank. MIT Press, Cambridge, Massachusetts, p. 88-98

Butman, B., Beardsley, R. C., Magnell, B., Frye, D., Vermersch, J. A., Schlitz, R., Limeburner, R., Wright. W R., Noble, M. A. (1982). Recent observations of the mean circulation on Georges Bank. J. phys. Oceanogr. 12 : 569-591

Butman, B., Loder, J. W., Beardsley, R. C. (1987). The seasonal mean circulation: observation and theory. In: Backus, R. H., Boume, D. W. (eds.) Georges Bank. MIT Press, Cambridge, Massachusetts, p. 125-138

Caddy, J. F. (1968). Underwater observations on scallop (Placopecten magellanicus) behaviour and drag efficiency. J. Fish. Res. Bd Can. 25: 2123-2141

Caddy, J. F. (1970). A method of surveying scallop populations from a submersible. J. Fish. Res. Bd Can. 27: 535-549

Caddy, J. F. (1972). Progressive loss of byssus attachment with size in the sea scallop, Placopecten magellanicus (G.). J. exp. mar Biol. Ecol. 9: 179-190

Caddy, J. F. (1973). Underwater observations on tracks of dredges and trawls and some effects of dredging on a scallop ground. J. Fish. Res. Bd Can. 30: 173-180

Caddy, J. F. (1989). A perspective on the population dynamics and assessment of scallop fisheries, with special reference to the sea scallop, Placopecten magellanicus (G.). In: Caddy, J. F. (ed.) Marine invertebrate fisheries: their assessment and management. Wiley, New York, p. $559-589$

Caddy, J. F., Carter, J. A. (1984). Macro-epifauna of the lower Bay of Fundy. Observations from a submersible and analysis of faunal adjacencies. Can. Tech. Rep. Fish. Aquat. Sci., 1254: $1-35$

Castagna, M., Kraeuter, J. N. (1977), Mercenaria culture using stone aggregate for predator protection. Proc. natl Shellfish. Ass. 67: 1-7

Chouinard, G. A (1984). Growth of the sea scallop (Placopecten magellanicus) on the Tormentine Bed. Northumberland Strait. CAFSAC (Can. Atlant. Fish. Sci. Advis. Comm.) Res. Docum. 84/61: 1-16

Cohen, E. B., Wright, W. R. (1978). Changes in the plankton on Georges Bank in relation to the physical and chemical environment dunng 1975-76. Comm. Meet. int. Coun. Explor Sea C.M.-ICES/L: 27: 1-12

Culliney, J. L. (1974). Larval development of the giant scallop Placopecten magellanicus (G.). Biol. Bull. mar biol. Lab., Woods Hole 147: 321-332

Dadswell, M. J. (1989). Potential for giant scallop (Placopecten magellanicus) aquaculture in Atlantic Canada. Proceedings 
of the Atlantic Aquaculture Fair, St. Andrews, New Brunswick. Bull. Aquaculture Ass. Can. (AAC) 89-1: 19-22

Dadswell, M. J., Weihs, D. (1990). Size-related hydrodynamic characteristics of the giant scallop. Placopecten magellanicus (Bivalvia: Pectinidae). Can. J. Zool. 68: 778-785

Dickie, L. M. (1955). Fluctuations in abundance of the giant scallop, Placopecten magellanicus (Gmelin), in the Digby area of the Bay of Fundy. J. Fish. Res. Bd Can. 12: 797-857

Dickinson, J. J., Wigley, R. L. (1981). Distribution of Gammaridean Amphipoda (Crustacea) on Georges Bank. NOAA. natl. mar. Fish. Serv, tech. Rep. Circ. 746: 1-25

Elliott, J. M. (1977). Some methods for the statistical analysis of samples of benthic invertebrates. Scientific Publ. 25 Freshwater Biological Ass., Cumbria, p. 160

Flagg, C. N. (1987). Hydrographic structure and variability. In: Backus, R. H., Bourne, D. W. (eds.) Georges Bank. MIT Press, Cambridge, Massachusetts, p. 108-124

Frontier, S. (1983). Stratégies d'échantillonnage en écologie. Coll. Ecologie, Masson, Paris, no. 170

Gaschütz, G., Pauly, D., David, N. (1980). A versatile BASIC program for fitting weight and seasonally oscillating length growth data. Comm. Meet. int. Coun. Explor Sea C.M.-ICES/D: 6: 1-23

Hoerner, S. F. (1975). Fluid dynamic lift. Hoerner, Bricktown, New Jersey, p. 253

Hurley, G. V., Tremblay, M. J., Couturier, C. (1987). Age estimation of sea scallop larvae (Placopecten magellanicus) from daily growth lines on shell. J. Northwest Atlant. Fish. Sci. 7(2): 123-129

Johnson, N. L., Kotz, S. (1969). Discrete distributions. Wiley J. \& Sons, New York

Krantz, D. E., Jones, D. S., Williams, D. F. (1984). Growth rates of the sea scallop. Placopecten magellanicus, determined from the ${ }^{18} \mathrm{O} /{ }^{16} \mathrm{O}$ record in shell calcite. Biol. Bull. mar. biol. Lab., Woods Hole 167; 186-199

Langton, R. W., Robinson, W. E. (1987). Ecology of the sea scallop Placopecten magellanicus (G.) in the gulf of Maine, USA. 6th int. Pectinid Workshop. Menai-Bridge, Wales, (mimeo)

Langton, R. W., Robinson, W. E. (1990). Faunal associations on scallop grounds in the western Gulf of Maine. J. exp. mar. Biol. Ecol. 144: 157-171

Langton, R. W., Robinson, W. E., Schick, D. (1987). Fecundity and reproductive effort of sea scallops Placopecten magellanicus from the Gulf of Maine. Mar. Ecol. Prog. Ser. 37 $19-25$

Larsen, P. F. Lee, R. M. (1978). Observations on the abundance, distribution and growth of post-larval sea scallops, Placopecten magellanicus, on Georges Bank. Nautilus 92(3): $112-116$

Loder, J. W., Wright, D. G., Garrett, C., Juszko, B.-A. (1982) Horizontal exchange on central Georges Bank. Can. J. Fish. Aquat. Sci. 39(8): 1130-1137

Lough, R. G., Trites, R. W. (1989). Chaetognaths and oceanography on Georges Bank. J. mar. Res. 47: 343-369

Lough, R. G., Valentine, P. C., Potter, D. C., Auditore, P. J., Bolz, G. R., Neilson, J. D., Perry, R. I. (1989). Ecology and distribution of juvenile cod and haddock in relation to sediment type and bottom currents on eastern Georges Bank. Mar. Ecol. Prog. Ser. 56: 1-12

MacDonald, B. A. (1986). Production and resource partitioning in the giant scallop Placopecten magellanicus grown on the bottom and in suspended culture. Mar. Ecol. Prog. Ser. 34: $79-86$

MacDonald, B. A., Thompson, R. J. (1985). Influence of temperature and food availability on the ecological energetics of the giant scallop Placopecten magellanicus. I. Growth rates of shell and somatic tissue. Mar. Ecol. Prog. Ser, 25 279-294

MacDonald, B. A., Thompson, R. J. (1988). Intraspecific variation in growth and reproduction in latitudinally differentiated populations of the giant scallop Placopecten magellanicus (Gmelin). Biol. Bull. mar. biol. Lab., Woods Hole 175(3): 361-371

McCullagh, P., Nelder, J. A. (1989). Generalized linear models, 2nd edn. Chapman \& Hall, London

Melvin, G. D., Dadswell, M. J., Chandler, R. A. (1985). Movement of scallops Placopecten magellanicus (G.), Mollusca: Pectinidae, on Georges Bank. CAFSAC (Can. Atlant. Fish Sci. Advis. Comm.) Res. Docum. 85/30: 1-29

Merrill, A. S., Edwards, R. L. (1976). Observations on mollusks from a navigation buoy with special emphasis on the sea scallop, Placopecten magellanicus. Nautilus 90:54-61

Merrill, A. S., Posgay, J. A. (1967). Juvenile growth of the sea scallop, Placopecten magellanicus. A. Rep. Am. malac. Un.: p. 51-52 (abstract)

Merrill, A. S., Posgay, J. A., Nichy, F. E. (1966). Annual marks on shell and ligament of sea scallop (Placopecten magellanicus). Fish. Bull. U.S. 65(2): 299-311

Mohn, R. K., Robert, G., Roddick, D. L. (1988). Georges Bank scallop stock assessment - 1987. CAFSAC (Can. Atlant. Fish. Sci. Advis. Comm.) Res. Doc. 88/3: p. 29

Naidu, K. S. (1970). Reproduction and breeding cycle of the giant scallop Placopecten magellanicus (G.) in Port au Port Bay, Newfoundland. Can. J. Zool. 48: 1003-1012

Naidu, K. S., Scaplen, R. (1976). Settlement and survival of the giant scallop, placopecten magellanicus larvae on enclosed polyethylene film collectors. F.A.O. Technical Conference on Aquaculture, Kyoto, Japan, 26 May-12 June 1976. FIR: AQ/Conf./76/E7: 1-5

O'Reilly, J. E., Evans-Zetlin, C., Busch, D.A. (1987). Primary production. In: Backus, R. H., Bourne, D. W. (eds.) Georges Bank. MIT Press, Cambridge, Massachusetts, p. 220-233

Orensanz, J. M. (1986). Size, environment, and density: the regulation of a scallop stock and its management implications. In: Jamieson, G. S., Bourne, N. (eds.) North Pacific workshop on stock assessment and management of Invertebrates. Can. Spec. Publ. Fish. Aquat. Sci. 92: 195-227

Payne, C. D. (1985). The GLIM (Generalized Linear Interactive Modelling) system manual, release 3.77. Numerical Algorithms Group. Payne, Oxford

Pierce, D. A., Schafer, D. W. (1986). Residuals in generalized linear models. J. Am. statis. Ass. 81: 977-986

Posgay, J. A. (1953). Sea scallop investigations. Commonwealth of Massachusetts. 6th Rep. on Investigations of Shellfish of Massachusetts. Dept of Natural Resources, Division of Marine Fisheries, Massachusetts, p. 8-24

Posgay, J. A. (1957). The range of the sea scallop. Nautilus 71 : $55-57$

Posgay, J. A. (1959). United States sea scallop research in subarea 5 during 1958. Int. Comm. Northw. Atl. Fish (ICNAF) annual Meet, Ser. 609, Doc. 10: 1-11

Posgay, J. A. (1962). Maximum yield per recruit of sea scallops. Int. Comm. Northw. Atl. Fish. (ICNAF) annual Meet. Ser. 1016, Doc. 73: 1-20

Posgay, J. A. (1963). Tagging as a technique in population studies of the sea scallop. Int. Comm. Northw. Atl. Fish (ICNAF) Spec. Pub. 4: 268-271

Posgay, J. A. (1979a). Population assessment of the Georges Bank sea scallop stocks. Rapp. P.-v.. Réun. Cons. int. Explor, Mer 175: 109-113

Posgay, J. A. (1979b). Depth as a factor affecting the growth rate of the sea scallop. Comm. Meet. int. Counc. Explor. Sea C.M.-ICES K: $27: 1-5$ 
Posgay, J. A. (1982). Movement of tagged sea scallop on Georges Bank. Mar. Fish. Rev. 43(4): 19-25

Ricker, W E. (1975). Computation and interpretation of biological statistics of fish populations. Bull. Fish. Res. Bd Can. 191. 1-382

Robert, G., Black, G. A. P. (1990). Georges Bank scallop stock assessment-1989. CAFSAC (Can. Atlant. Fish. Sci. Advis. Comm.) Res. Doc. 90/19: 1-30

Robert, G., Jamieson, G. S., Lundy, M. J. (1982). Profile of the canadian offshore scallop fishery on Georges Bank, 1978 to 1981. CAFSAC (Can. Atlant. Fish. Sci. Advis. Comm.) Res. Doc. 82/15: 1-47

Seed, R. (1980). Shell growth and form in the Bivalvia. In: Rhoads, D. C., Lutz, R. A. (eds.) Skeletal growth of aquatic organisms. Plenum Press, New-York, p. 23-68

Serchuk, F. M., Wigley, S. E. (1984). Results of the 1984 USA sea scallop research vessel survey: status of sea scallop resources in the Georges Bank, mid-Atlantic, and Gulf of Maine regions and abundance and distribution of Iceland scallops off the southeastern coast of Cape Cod. Woods Hole Laboratory Reference Document 84-34. National Marine Fisheries Service, Northeast Fisheries Center, Woods Hole, Massachusetts (mimeo)

Serchuk, F. M. Wigley, S. E. (1986). Abundance, size composition and recruitment of sea scallops in the USA Georges Bank and mid-Atlantic regions: results of the 1986 USA sea scallop research vessel survey. Woods Hole Laboratory Reference Document 86-15. National Marine Fisheries Service, Northeast Fisheries Center, Woods Hole, Massachusetts (mimeo)

Serchuk, F. M., Wood, P. W. Posgay, J. A., Brown, B. E. (1979). Assessment and status of sea scallop (Placopecten magellanicus ) populations off the northeast coast of the United States. Proc. natl Shellfish. Ass. 69: 161-191

Shumway, S. A., Selvin, R., Schick, D. F. (1987). Food resources related to habitat in the scallop Placopecten magellanicus (Gmelin, 1791): a qualitative study. J. Shellfish Res. 6(2): 89-95

Sinclair, M., Mohn, R. K., Robert, G., Roddick, D. (1985). Considerations for the effective management of Atlantic scallops. Can. Tech. Rep. Fish. Aquat. Sci. 1382: 1-113

This article was presented by G. C. Harding, Dartmouth, Canada
Snedecor, G. W., Cochran, W. G. (1967). Statistical methods. 6 th edn. University of Iowa Press, Ames

Stephens, P. J., Boyle, P. R. (1978). Escape response of the queen Chlamys opercularis (L.) (Mollusca: Bivalvia). Mar. Behav. Physiol. 5: 103-113

Stevenson, J. A., Dickie, L. M. (1954). Annual growth rings and rate of growth of the giant scallop. Placopecten magellanicus (G.) in the Digby area of the bay of Fundy. J. Fish. Res. Bd Can. 11(5): 660-671

Tan, F. C., Cai, D., Roddick, D. L. (1988). Oxygen isotope studies on sea scallops, Placopecten magellanicus, from Browns Bank, Nova Scotia. Can. J. Fish. Aquat. Sci. 45 (8): 1378-1386

Thomas, G. E., Gruffydd, LL. D. (1971). The types of escape reactions elicited in the scallop Pecten maximus by selected sea-star species. Mar. Biol. 10: 87-93

Thornbun, I. W., Gruffydd, LL. D. (1979). Studies of the behaviour of the scallop Chlamys opercularis (L.), and its shell in flowing sea water. J. mar. biol. Ass. U.K. 59: $1003-1023$

Thouzeau, G. (1989). Déterminisme du pré-recrutement de Pecten maximus (L.) en baie de Saint-Brieuc. Thèse doc. Université Bretagne Occidentale, Brest

Thouzeau, G., Hily, C. (1986). A.QUA.R.E.V.E.: une technique nouvelle d'échantillonnage quantitatif de la macrofaune épibenthique des fonds meubles. Oceanol. Acta 9(4): 509-513

Thouzeau, G., Lehay, D. (1988). Variabilité spatio-temporelle de la distribution, de la croissance et de la survie des juvéniles de Pecten maximus (L.) issus des pontes de 1985 en baie de Saint-Brieuc. Oceanol. Acta 11(3): $267-284$

Tremblay, M. J., Sinclair, M. (1990). Sea scallop larvae Placopecten magellanicus on Georges Bank: vertical distribution in relation to water column stratification and food. Mar. Ecol. Prog. Ser. 61. 1-15

Underwood, A. J. (1981). Techniques of analysis of variance in experimental marine biology and ecology, Oceanogr. mar. Biol. A. Rev. 19: 513-605

Winer, B. J. (1971). Statistical principles in experimental design, 2nd edn. McGraw-Hill Inc., New York

Manuscript first received: October 3, 1990

Revised version accepted: May 24, 1991 